\title{
Immobilization of $\mathrm{Cr}(\mathrm{VI})$ in Soil Using a Montmorillonite-Supported Carboxymethyl Cellulose-Stabilized Iron Sulfide Composite: Effectiveness and Biotoxicity Assessment
}

\author{
Dading Zhang ${ }^{1,+}$, Yanqiu Xu ${ }^{1,+}$, Xiaofei Li ${ }^{2}$, Zhenhai Liu ${ }^{3}$, Lina Wang ${ }^{1}$, Chaojun Lu ${ }^{4}$, \\ Xuwen $\mathrm{He}^{1}$, Yan Ma ${ }^{1, *}$ and Dexun Zou ${ }^{2, *}$ \\ 1 School of Chemical and Environmental Engineering, China University of Mining and Technology (Beijing), \\ Beijing 100083, China; tmaczdd02@163.com (D.Z.); xuyq15871041327@163.com (Y.X.); \\ m18850341814@163.com (L.W.); 108137@cumtb.edu.cn (X.H.) \\ 2 College of Chemical Engineering, Beijing University of Chemical Technology, Beijing 100029, China; \\ lixiaofei203@126.com \\ 3 College of Environmental Science and Engineering, Nankai University, Tianjin 300350, China; \\ hiram0823@163.com \\ 4 Chinese Research Academy of Environmental Sciences, Beijing 100012, China; lucj@craes.org.cn \\ * Correspondence: yanma@cumtb.edu.cn (Y.M.); zoudx@mail.buct.edu.cn (D.Z.); \\ Tel.: +86-158-1012-8622 (Y.M.); +86-159-1066-5628 (D.Z.) \\ + Co-first authors.
}

Received: 18 July 2020; Accepted: 19 August 2020; Published: 21 August 2020

\begin{abstract}
A novel composite of montmorillonite-supported carboxymethyl cellulose-stabilized nanoscale iron sulfide (CMC@MMT-FeS), prepared using the co-precipitation method, was applied to remediate hexavalent chromium $(\mathrm{Cr}(\mathrm{VI}))$-contaminated soil. $\mathrm{Cr}(\mathrm{VI})$-removal capacity increased with increasing FeS-particle loading. We tested the efficacy of CMC@MMT-FeS at three concentrations of FeS: 0.2, 0.5, and $1 \mathrm{mmol} / \mathrm{g}$, hereafter referred to as 0.2 CMC@MMT-FeS, 0.5 CMC@MMT-FeS, and 1.0 CMC@MMT-FeS, respectively. The soil Cr(VI) concentration decreased by $90.7 \%$ (from an initial concentration of 424.6 to $39.4 \mathrm{mg} / \mathrm{kg}$ ) after 30 days, following addition of $5 \%$ (composite-soil mass proportion) 1.0 CMC@MMT-FeS. When 2\% 0.5 CMC@MMT-FeS was added to Cr(VI)-contaminated soil, the $\mathrm{Cr}(\mathrm{VI})$ removal efficiency, as measured in the leaching solution using the toxicity characteristic leaching procedure, was $90.3 \%$, meeting the environmental protection standard for hazardous waste $(5 \mathrm{mg} / \mathrm{kg}$ ). The European Community Bureau of Reference (BCR) test confirmed that the main $\mathrm{Cr}$ fractions in the soil samples changed from acid-exchangeable fractions to oxidable fractions and residual fractions after 30 days of soil remediation by the composite. Moreover, the main complex formed during remediation was $\mathrm{Fe}(\mathrm{III})-\mathrm{Cr}$ (III), based on BCR and X-ray photoelectron spectroscopy analyses. Biotoxicity of the remediated soils, using Vicia faba and Eisenia foetida, was analyzed and evaluated. Our results indicate that CMC@MMT-FeS effectively immobilizes $\mathrm{Cr}(\mathrm{VI})$, with widespread potential application in $\mathrm{Cr}(\mathrm{VI})$-contaminated soil remediation.
\end{abstract}

Keywords: potential toxic metal contamination; CMC@MMT-FeS; soil remediation; BCR test; toxicity characteristic leaching procedure; biotoxicity assessment

\section{Introduction}

Potential toxic metal contamination is a global concern, because toxic metals can bioaccumulate in the food chain, causing high levels of toxicity in the human body [1-3]. Chromium (Cr), a potential toxic metal, is often released into water or soil from chromate manufacturing, textile dyeing, tanneries, 
and metal electroplating, due to poor waste management $[4,5]$. $\mathrm{Cr}(\mathrm{III})$ and $\mathrm{Cr}(\mathrm{VI})$ are two common species of $\mathrm{Cr}$ in the environment. $\mathrm{Cr}(\mathrm{III})$ - which comes from insoluble substances such as $\mathrm{Cr}(\mathrm{OH})_{3}$ and $\mathrm{Cr}_{2} \mathrm{O}_{3}$-has a relatively low biotoxicity and is more stable; $\mathrm{Cr}(\mathrm{VI})$ - which comes from compounds such as $\mathrm{CrO}_{4}{ }^{2-}, \mathrm{HCrO}_{4}{ }^{-}$, and $\mathrm{Cr}_{2} \mathrm{O}_{7}{ }^{2-}$-is easier to mobilize than $\mathrm{Cr}(\mathrm{III})$, particularly in soil [6-8]. The biological toxicity of $\mathrm{Cr}(\mathrm{VI})$ is over 100 times that of $\mathrm{Cr}(\mathrm{III})$ [9]. Thus, $\mathrm{Cr}(\mathrm{VI})$ is regarded as the most bio-toxic form of $\mathrm{Cr}$; its concentration in water and soil should be kept low, owing to its high toxicity, carcinogenicity, and potential for bioaccumulation [10,11].

$\mathrm{Cr}(\mathrm{VI})$ can be converted to $\mathrm{Cr}(\mathrm{III})$ in the presence of reductants, such as ferrous iron, manganous ion, organic phenols, and a reducing microorganism [12,13]. $\mathrm{Cr}$ (III) can be oxidized to $\mathrm{Cr}(\mathrm{VI})$ through interaction with manganese dioxide, and the conversion is substantially influenced by the equilibrium between the dissolved and solid phases of $\mathrm{Cr}(\mathrm{III})$; furthermore, the kinetics are slow [14]. When $\mathrm{Cr}(\mathrm{VI})$ is converted into $\mathrm{Cr}(\mathrm{III})$, various precipitant compounds are formed, such as $\mathrm{Cr}(\mathrm{OH})_{x}, \mathrm{Cr}_{2} \mathrm{O}_{3}$, and $\mathrm{Fe}(\mathrm{III})-\mathrm{Cr}(\mathrm{III})$ hydroxides, which reduce its risk to humans $[15,16]$. Therefore, converting easily mobile and highly toxic $\mathrm{Cr}(\mathrm{VI})$ compounds into stable and low toxicity $\mathrm{Cr}(\mathrm{III})$ compounds is an effective remediation strategy to alleviate the threat of $\mathrm{Cr}(\mathrm{VI})$ to ecosystems.

As urbanization increases, so do the number of $\mathrm{Cr}(\mathrm{VI})$-contaminated sites in need of remediation, and these sites can then be used for residential or commercial purposes [17]. In recent years, methods such as bioremediation, chemical reduction, and immobilization have been used to remove $\mathrm{Cr}(\mathrm{VI})$ from water and soil [18-20]. Chemical reduction is widely used owing to its high efficiency and low cost [21]. Inorganic or organic electron donors can reduce $\mathrm{Cr}$ (VI) to $\mathrm{Cr}$ (III) and form insoluble $\mathrm{Cr}$ (III) hydroxides in the reduction process [22-24]. Iron minerals, such as goethite, hematite, mackinawite, and pyrite, in soil and subsurface sediment have been shown to reduce $\mathrm{Cr}$ (VI) to $\mathrm{Cr}(\mathrm{III})$ [25-28]. However, the reduction rate is slow, and it depends on the iron content in minerals [29]. Ferrous compounds, especially ferrous sulfate $\left(\mathrm{FeSO}_{4}\right)$, have been widely studied and used in the remediation of $\mathrm{Cr}(\mathrm{VI})$-contaminated sites [30]. However, this approach can cause various problems when the pure ferrous reagent is added to a $\mathrm{Cr}(\mathrm{VI})$-contaminated solution or soil, including excess production of reagents in soil, inadequate reduction of $\mathrm{Cr}(\mathrm{VI})$, and an overload of anions in soil particles. Hence, many alternative species of iron materials have been developed for the remediation of $\mathrm{Cr}(\mathrm{VI})$-contaminated water or soil. Owing to the highly active nature of nanomaterials, the removal of $\mathrm{Cr}(\mathrm{VI})$ by nanoscale zero-valent iron (nZVI) and biochar-, rock wool-, and graphite-loaded nZVI has been widely studied [31-34]. However, the use of nZVI has many drawbacks, including high costs and strict reductive conditions, limiting its application.

Recent studies have shown that iron sulfide (FeS) is highly efficient in immobilizing $\mathrm{Cr}(\mathrm{VI})$ in water or soil because it can provide $\mathrm{Fe}(\mathrm{II})$ and $\mathrm{S}(-\mathrm{II})$ species that reduce $\mathrm{Cr}(\mathrm{VI})$ to $\mathrm{Cr}(\mathrm{III})$. Compared with iron sulfide-containing minerals, $\mathrm{FeS}$ particles are small with a large specific surface area, which contributes to their higher reactivity [35]. They can absorb $\mathrm{Cr}(\mathrm{VI})$ via surface reactions [36]. However, FeS particles tend to aggregate, impeding their effectiveness [37]. Therefore, FeS-modified materials are being studied: for example, chitosan-stabilized FeS effectively remediated $\mathrm{Cr}(\mathrm{VI})$-contaminated aqueous samples [38], and carboxymethyl cellulose (CMC)-stabilized FeS remediated $\mathrm{Cr}(\mathrm{VI})$-contaminated water and soil [39-41]. Here, we present a novel composite comprising CMC-stabilized FeS on montmorillonite (MMT), preventing the aggregation of the FeS particles and enhancing their dispersal and utilization in soils. CMC, as a common anionic high-polymer cellulose, can interact with multivalent cations owing to its numerous carboxyl and hydroxyl groups. It is usually applied as a stabilizer in suspension owing to its electrostatic repulsion and space-resistance effects [42-44]. MMT, as a typical 2:1 phyllosilicate resource, is abundant, inexpensive, and environmentally friendly, and has been frequently applied as an adsorbent or supporting material in environmental remediation $[45,46]$. Its large surface area contributes to the dispersion of FeS particles. Acid modification can remove impurities from the MMT, and further enhance the mineral pore spaces and support more target substance [47].

This study used an MMT-supported and CMC-stabilized FeS composite (CMC@MMT-FeS) to remediate $\mathrm{Cr}(\mathrm{VI})$ contamination in soil and aqueous samples. We investigated the following aspects 
of this novel composite: (1) its composition and surface properties; (2) how effectively it remediates $\mathrm{Cr}(\mathrm{VI})$ contamination, compared with an $\mathrm{FeSO}_{4}$ reagent; (3) the $\mathrm{Cr}$ fractions in the soil before and after remediation and the mechanisms of $\mathrm{Cr}(\mathrm{VI})$ immobilization; and (4) the biotoxicity of soils before and after remediation. Our objective is to provide a reference for the use of CMC@MMT-FeS to remediate $\mathrm{Cr}(\mathrm{VI})$-contaminated environments.

\section{Materials and Methods}

\subsection{Chemicals and Materials}

Ultrafine MMT powder was purchased from Lingshou Mineral Powder Factory (Shijiazhuang, China). The analytical-grade chemicals, including sodium sulfide nonahydrate $\left(\mathrm{Na}_{2} \mathrm{~S} \cdot 9 \mathrm{H}_{2} \mathrm{O}\right)$, ferrous sulfate heptahydrate $\left(\mathrm{FeSO}_{4} \cdot 7 \mathrm{H}_{2} \mathrm{O}\right)$, potassium chromate $\left(\mathrm{K}_{2} \mathrm{CrO}_{4}\right)$, sodium nitrate $\left(\mathrm{NaNO}_{3}\right)$, acetic acid $\left(\mathrm{C}_{2} \mathrm{H}_{4} \mathrm{O}_{2}\right)$, hydrochloric acid $(\mathrm{HCl})$, sodium hydroxide $(\mathrm{NaOH})$, and ethanol were purchased from the Beijing Chemical Regent Factory (Beijing, China). CMC was purchased from Anpel Laboratory Technologies (Shanghai, China). All solutions were prepared with pure water of $>18 \mathrm{M} \Omega ~ c m^{-1}$.

The soil samples were collected from an electroplating workshop of a factory in Hefei, China, and the $\mathrm{Cr}(\mathrm{VI})$ content in the soil was $24.5 \pm 2 \mathrm{mg} / \mathrm{kg}$, which was below the risk intervention value [48]. Stones and plant roots were removed from the soil samples, which were air-dried, ground, and then sieved through a $2 \mathrm{~mm}$ standard mesh. The physicochemical properties of the soil samples are shown in Table S1 (Supplementary Materials). $\mathrm{Cr}(\mathrm{VI})$-contaminated soil was prepared as follows: $1 \mathrm{~L}$ of $\mathrm{K}_{2} \mathrm{CrO}_{4}$ solution at a concentration of $1.865 \mathrm{~g} / \mathrm{L}$ was slowly mixed with $1 \mathrm{~kg}$ of soil, and then homogenized by vigorous stirring. The pretreated soil was then air-dried under natural conditions and aged for $60 \mathrm{~d}$. The aged soil samples were pulverized into fine particles and passed through a $2 \mathrm{~mm}$ standard sieve. The pulverized soil was stored in a zip-lock bag in dark conditions until further analysis. $\mathrm{The} \mathrm{Cr}(\mathrm{VI})$ concentration of the prepared contaminated soil samples was $424.6 \pm 17 \mathrm{mg} / \mathrm{kg}$.

\subsection{Preparation and Characterization of CMC@MMT-FeS}

The composite CMC@MMT-FeS sample was synthesized via a chemical co-precipitation method, as previously reported [5]. First, $9.54 \mathrm{~g}$ of purified MMT (Supplementary Materials Section 1) was transferred into a $2 \mathrm{~L}$ anaerobic Erlenmeyer flask containing $1 \mathrm{~L}$ of pure water; high purity nitrogen gas was added to remove the dissolved oxygen. After $1 \mathrm{~h}, 20 \mathrm{~mL}$ of freshly prepared $2.5 \mathrm{mmol} / \mathrm{L} \mathrm{FeSO}_{4}$ solution was added to this mixture, which was magnetically stirred for $30 \mathrm{~min}$ while nitrogen was continuously purged into the flask, resulting in the formation of MMT- $\mathrm{Fe}^{2+}$. Subsequently, $3.82 \mathrm{~mL}$ of CMC solution $(0.5 \%, w / w)$ was added, resulting in the formation of CMC@MMT-Fe ${ }^{2+}$ complexes. Finally, $10 \mathrm{~mL}$ of $6 \mathrm{mmol} / \mathrm{L} \mathrm{Na}_{2} \mathrm{~S}$ solution was added drop by drop to the mixture with continuous magnetic stirring. The $\mathrm{S}^{2-}$ combined with the CMC@MMT-Fe ${ }^{2+}$ to form the CMC@MMT-FeS composite containing $0.5 \mathrm{mmol} / \mathrm{g}$ FeS. The chemical reaction is shown in Equations (1)-(3).

$$
\begin{gathered}
\mathrm{MMT}+\mathrm{Fe}\left(\mathrm{H}_{2} \mathrm{O}\right)_{6}{ }^{2+} \rightarrow \mathrm{MMT}-\mathrm{Fe}\left(\mathrm{H}_{2} \mathrm{O}\right)_{6}{ }^{2+} \\
\mathrm{MMT}-\mathrm{Fe}\left(\mathrm{H}_{2} \mathrm{O}\right)_{6}{ }^{2+}+\mathrm{CMC} \rightarrow \mathrm{CMC} @ M M T-\mathrm{Fe}\left(\mathrm{H}_{2} \mathrm{O}\right)_{6}{ }^{2+} \\
\text { CMC@MMT }-\mathrm{Fe}\left(\mathrm{H}_{2} \mathrm{O}\right)_{6}{ }^{2+}+\mathrm{S}^{2-} \rightarrow \text { CMC@MMT-FeS }
\end{gathered}
$$

The final composite, containing FeS at 0.2, 0.5, and $1 \mathrm{mmol} / \mathrm{g}$ (hereafter 0.2 CMC@MMT-FeS, 0.5 CMC@MMT-FeS, and 1.0 CMC@MMT-FeS, respectively), was prepared using the above procedure. The precipitant was filtered and vacuum freeze-dried for subsequent use.

The crystalline structures of MMT and CMC@MMT-FeS particles were visualized using X-ray diffraction (XRD, Shimadzu Corporation, Japan) with $\mathrm{Cu}-\mathrm{K}_{\alpha}$ radiation $(\lambda=0.15418 \mathrm{~nm})$. The surface chemicals were measured using Fourier transform infrared spectroscopy (FTIR, MODEL 205, Nicolet Corporation, USA) equipped with a deuterated triglycine sulfate detector. The specific surface areas and internal microporous properties of the MMT and composite were analyzed using the 
Brunauer-Emmett-Teller (BET) method via $\mathrm{N}_{2}$ adsorption-desorption at $77 \mathrm{~K}$, on an ASAP 2460 Surface Area and Porosity Analyzer (Micromeritics, Norcross, GA, USA).

\subsection{Remediation of $\mathrm{Cr}(\mathrm{VI})$-Contaminated Soil}

Fourteen Cr-contaminated soil samples (100 g) (prepared as per Section 2.1) were weighed into $750 \mathrm{~mL}$ polypropylene plastic boxes. To explore the process of $\mathrm{Cr}(\mathrm{VI})$ immobilization in soil using the composite materials, the $\mathrm{Cr}(\mathrm{VI})$ concentration and oxidation-reduction potential (ORP) in the soil samples were measured at specific times $(1,2,3,5,7,10,15$, and $30 \mathrm{~d})$ in three treatments, comprising the addition of 0.5 CMC@MMT-FeS, 1.0 CMC@MMT-FeS (5\% composite-soil mass proportions), and $2.5 \mathrm{mmol} \mathrm{FeSO}_{4}$ reagent. To assess the optimum reaction dosage and $\mathrm{Cr}(\mathrm{VI})$ immobilization effect, $1 \%, 2,3,5$, and $10 \%$ doses (composite-soil mass proportions) of the 0.5 CMC@MMT-FeS were added to the contaminated soil for remediation. Additionally, 0.5, 1.0, 1.5, 2.5, and $5.0 \mathrm{mmol}$ of the $\mathrm{FeSO}_{4}$ reagent, providing the same amount of $\mathrm{Fe}(\mathrm{II})$ as the 1, 2, 3, 5, and 10\% doses of the $0.5 \mathrm{CMC} @ \mathrm{MMT}-\mathrm{FeS}$, were added. A blank control group (CK, containing no immobilization complex or reagent) was also prepared. The sample mixtures were stirred well, and then the container was sealed and incubated for $60 \mathrm{~d}$ at room temperature $\left(23 \pm 2{ }^{\circ} \mathrm{C}\right)$. During the incubated period, the soil moisture content at $50 \%$ was maintained by weighing method. The effectiveness of $\mathrm{Cr}(\mathrm{VI})$ immobilization in the soil was estimated by measuring the concentrations of $\mathrm{Cr}(\mathrm{VI})$ in remediated soils. $\mathrm{The} \mathrm{Cr}(\mathrm{VI})$ immobilization efficiency was calculated as per Equation (4):

$$
\text { Immobilization efficiency }(\%)=\left(1-C_{t} / C_{0}\right) \times 100
$$

where $C_{t}$ and $C_{0}$ are the $C r(V I)$ concentrations $(\mathrm{mg} / \mathrm{kg})$ in the contaminated soil at time $t$ and initially, respectively. All experiments were conducted in an anaerobic environment, in duplicate.

\subsection{Evaluation of $\mathrm{Cr}(\mathrm{VI})$ Stability in the Soil after Remediation}

Toxicity characteristic leaching procedure (TCLP) tests were performed to evaluate the potential for metal immobilization in the untreated soil, and in soils remediated with the composite and $\mathrm{FeSO}_{4}$. The TCLP experiments followed the Environmental Protection Industry Standard of China (China, $\mathrm{HJ} / \mathrm{T}$ 300-2007) [49]. In short, $2 \mathrm{~g}$ of soil samples before and after remediation were transferred into $50 \mathrm{~mL}$ centrifuge tubes, and then $40 \mathrm{~mL}$ of extraction solution $(5.7 \mathrm{~mL} 99-100 \%$ acetic acid and $64.3 \mathrm{~mL}$ $1 \mathrm{M} \mathrm{NaOH}$ in $1 \mathrm{~L}$ pure water, $\mathrm{pH} 4.93 \pm 0.05$ ) was added to obtain a liquid-to-solid ratio of 20:1. The samples were shaken rotationally for $18 \mathrm{~h}$ at room temperature $\left(23 \pm 2{ }^{\circ} \mathrm{C}\right)$. The supernatants containing the $\mathrm{Cr}(\mathrm{VI})$ were then passed through a $0.8 \mu \mathrm{m}$ micro-filter for analysis.

The three-step sequential procedure proposed by the European Community Bureau of Reference (BCR) was used to analyze heavy metals fractions in the soil [50]. Fractions of $\mathrm{Cr}$ in the soil before and after remediation were extracted using a modified three-step sequential procedure [51], for extraction of (1) the acid-exchangeable fraction, (2) the reducible fraction, and (3) the oxidizable fraction, followed by extraction of the residual fraction (Supplementary Materials Section 2, Table S2). The supernatant liquids were kept at $4{ }^{\circ} \mathrm{C}$ for subsequent measurements.

\subsection{Biotoxicity Assessment of Cr(VI)-Contaminated Soils after Remediation}

To explore the effect of CMC@MMT-FeS on the biotoxicity of $\mathrm{Cr}(\mathrm{VI})$-contaminated soil, Vicia faba and Eisenia foetida were used for biotoxicity testing, using the contaminated soil before and after remediation $[52,53]$.

The $V$. faba micronucleus test was conducted according to Kanaya et al. [54-56]. The secondary roots of $V$. faba (1-2 cm long, Supplementary Materials Section 3) were suitable for the micronucleus test. The secondary roots were immersed in a Petri dish of soil extract (Supplementary Materials Section 4$)$ for 24,48 , or $72 \mathrm{~h}$ at room temperature $\left(23 \pm 2{ }^{\circ} \mathrm{C}\right)$. The roots from at least two seedlings were tested in each extract, and five root tips were randomly selected from each seedling. The secondary 
roots were then placed into Carnoy's solution (acetic acid: ethanol 1:3, v/v) and fixed overnight at $4{ }^{\circ} \mathrm{C}$. Next, they were cleaned with deionized water and transferred to $70 \%$ ethanol for storage. They were hydrolyzed in $1 \mathrm{M} \mathrm{HCl}$ for $15 \mathrm{~min}$ at $60^{\circ} \mathrm{C}$. Thereafter, $1 \mathrm{~mm}$ of root-tip meristem was placed on a glass slide with $1 \%$ aceto-orcein reagent $(1 \mathrm{~g}$ orcein, $45 \mathrm{~mL}$ acetic acid, $55 \mathrm{~mL}$ deionized water) for staining for $15 \mathrm{~min}$. Then, roots were washed, pressed, and microscopically examined. At least 1000 cells were scored for each root tip. The pollution index (PI), an important index for evaluating the degree of environmental toxicity in living organisms, was calculated using Equation (5):

$$
\mathrm{PI}=M C N_{\text {remediation }} / M C N_{C K}
$$

where $M C N_{\text {remediation }}$ and $M C N_{C K}$ are the $V$. faba micronucleus rates in the remediation and $C K$ groups, respectively.

According to Sivakumar and Subbhuraam (2005), the median lethal concentration of Cr(VI) for E. foetida is about $220 \mathrm{mg} / \mathrm{kg}$ [57]. Background soil was added to the experimental soil samples to achieve the proper dilution. The $\mathrm{Cr}(\mathrm{VI})$ concentrations in the original and diluted soil after remediation are shown in Table S3. Samples of $300 \mathrm{~g}$ diluted soil and 10 randomly selected E. foetida, which had been incubated in the laboratory environment for two weeks, were placed in a 1 L beaker, which was placed in dark conditions at room temperature $\left(23 \pm 2{ }^{\circ} \mathrm{C}\right)$. The daily mortality of the earthworms was recorded. One or two E. foetida were taken for intestinal cleaning, and weighed at 1, 3, 7 and $14 \mathrm{~d}$. They were then cut into pieces and homogenized in buffer solution at a solid-liquid mass ratio of 1:9. The tissue solution was transferred and centrifuged at $3000 \mathrm{rpm}$ for $10 \mathrm{~min}$. The superoxide dismutase (SOD) and peroxidase (POD) activity levels in the supernatants were measured using commercial kits (A001-3-2 and A084-1-1, Jiancheng Bioengineering Institute, Nanjing, China).

\subsection{Analysis Methods}

$\mathrm{Cr}(\mathrm{VI})$ in soils was extracted using a heater with $\mathrm{MgCl}_{2}$ and phosphate buffer $(\mathrm{pH}=7)$ in alkaline medium ( $\mathrm{Na}_{2} \mathrm{CO}_{3} / \mathrm{NaOH}$ solution), and its concentration was measured using flame atomic absorption spectrophotometry (China, HJ/T 687-2014) [58]. Cr(VI) concentrations in the solutions were determined using a UV2200 spectrophotometer (Shanghai Sunny Hengping Scientific Instrument Co., Ltd., Shanghai, China) following the diphenyl-carbazide spectrophotometric method (China, GB 7467-87) [59]. The soil redox potential was determined according to the China national standard SL 94-1994, using an SX731 portable redox potential tester (Sanxin, Shanghai, China). In addition, the surface elements of the soil before and after remediation were investigated via X-ray photoelectron spectroscopy (XPS, Escalab 250, Thermo Fisher, USA) with a monochromatic Al K $\alpha$ source.

\section{Results and Discussion}

\subsection{Characterization of Materials}

Modified MMT and raw materials were examined using the XRD technique; patterns with a diffraction angle of $2 \theta$ ranging from $5^{\circ}$ to $40^{\circ}$ are shown in Figure 1 . The composite diffraction pattern had two new peaks, at $27.5 \AA$ and $30.8 \AA$, which were attributed to the presence of $\mathrm{Fe}_{2} \mathrm{O}_{3}$ and $\mathrm{FeS}$, respectively $[60,61]$. This indicates that nano-FeS was successfully loaded on the surface layers of the MMT. Additionally, $\mathrm{Fe}_{2} \mathrm{O}_{3}$ may be a product of the oxidation of $\mathrm{Fe}(\mathrm{OH})_{2}$ and $\mathrm{Fe}(\mathrm{OH})_{3}$; it is also possible that $\mathrm{FeS}$ was oxidized and partly deactivated. By estimating the basic spacing of $\mathrm{D}_{001}$, we found that the interlayer distance of the modified MMT did not expand, indicating that nano-FeS had not formed in the clay interlayer space. This provides further evidence that the FeS nanoparticles were mainly loaded on the surfaces of the MMT. 


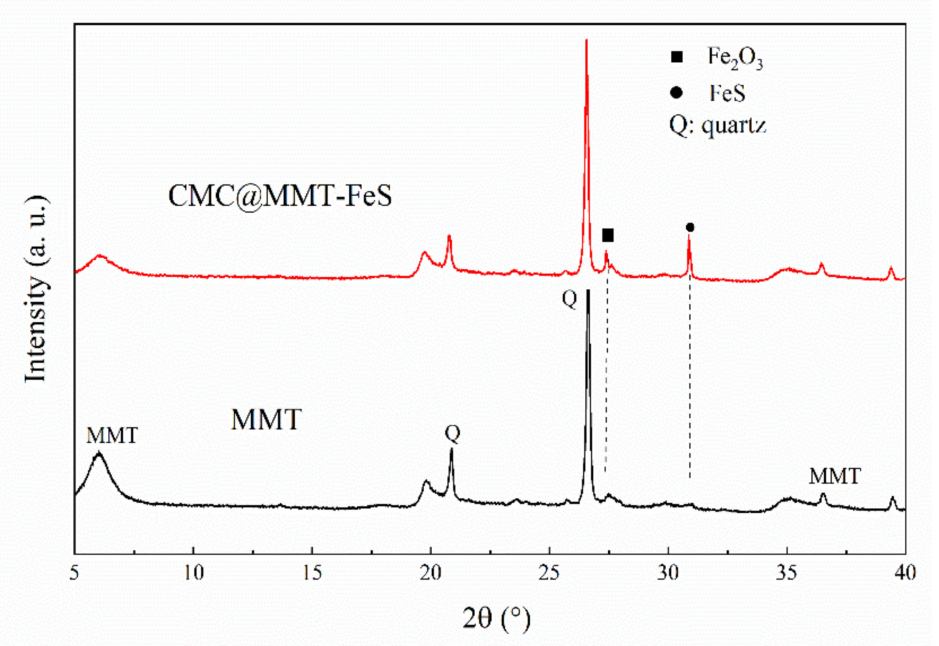

Figure 1. X-ray diffraction (XRD) pattern analysis of montmorillonite (MMT) and carboxymethyl cellulose-stabilized nanoscale iron sulfide (CMC@MMT-FeS).

The characteristic stretching frequencies of the MMT and modified materials were compared using the FTIR spectra (Figure 2). The characteristic peaks were mainly distributed in the $500-4000 \mathrm{~cm}^{-1}$ range. The changes in transmittance at 976 and $800 \mathrm{~cm}^{-1}$ were related to the $\mathrm{Si}-\mathrm{O}$ bond bending vibration and $\mathrm{Mg}-\mathrm{OH}$ stretching vibration. The CMC@MMT-FeS spectrum had new peaks at 3280, $2922,2855,1242$, and $1153 \mathrm{~cm}^{-1}$. The $3280 \mathrm{~cm}^{-1}$ peak was attributed to the stretching of N-H bonds [62]. The 2922 and $2855 \mathrm{~cm}^{-1}$ peaks were attributed to the asymmetric and symmetric stretching vibration of the $\mathrm{C}-\mathrm{H}$ bonds in the $-\mathrm{CH}_{2}$ group [63], whereas the 1242 and $1153 \mathrm{~cm}^{-1}$ peaks were attributed to $\mathrm{C}-\mathrm{O}-\mathrm{C}$ stretching vibration [64]. There were relatively more intense stretching bands at 1741 and $1647 \mathrm{~cm}^{-1}$, which can be attributed to the $\mathrm{C}=\mathrm{O}$ stretching vibration, and to the $\mathrm{C}-\mathrm{O}$ or $\mathrm{N}-\mathrm{H}$ bending vibration, respectively. The $1539 \mathrm{~cm}^{-1}$ peak was attributed to carboxylate absorption. These results reveal that nano-FeS particles were attached to $\mathrm{CMC}$ via the carboxylate and hydroxyl groups, and that functional groups such as $\mathrm{C}=\mathrm{O}, \mathrm{C}-\mathrm{O}-\mathrm{C}$, and $\mathrm{N}-\mathrm{H}$ may play important roles in the process of loading $\mathrm{CMC}$ and nano-FeS particles onto the surface of the MMT.

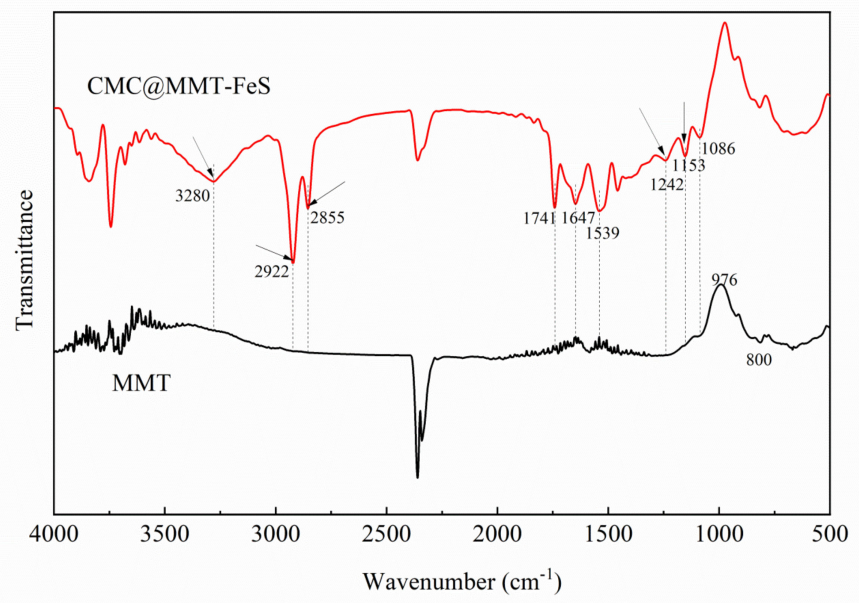

Figure 2. Fourier transform infrared spectral pattern analyses of montmorillonite (MMT) and CMC@MMT-FeS.

The specific surface parameters of the MMT and the CMC@MMT-FeS were studied using Brunauer-Emmett-Teller (BET) analysis. The specific surface area of the MMT increased from 84.24 to $88.98 \mathrm{~m}^{2} / \mathrm{g}$, but the pore volume decreased slightly from 0.110 to $0.107 \mathrm{~cm}^{3} / \mathrm{g}$ after modification. 
The augmentation of the specific surface area was a result of FeS particles being loaded onto the surface of MMT and increasing the MMT surface roughness. Some FeS particles were generated by co-precipitation in the pores, which partly blocked the pores of MMT, thereby reducing the unit pore volume. The BET analysis results show that, although the FeS particles in the composite were deposited mainly on the surface of the material, they also formed in the pores of the MMT.

\subsection{Effect of $\mathrm{Cr}(V I)$ Immobilization in Soil by CMC@MMT-FeS}

The removal efficacy of the different prepared composite on $\mathrm{Cr}(\mathrm{VI})$ in aqueous solution was assessed during preliminary experiments (Supplementary Materials Section 5): in solution, the $\mathrm{Cr}(\mathrm{VI})$ removal capacities of the three types of composite, ranked in order of capacity, were as follows: 1.0 CMC@MMT-FeS > 0.5 CMC@MMT-FeS > 0.2 CMC@MMT-FeS (Figure S1). In aqueous solution, the $\mathrm{Cr}(\mathrm{VI})$-removal capacity of the composite was positively associated with FeS loading. Additionally, pseudo-first-order and pseudo-second-order kinetic models were used to fit the amount of $\mathrm{Cr}(\mathrm{VI})$ removed by the modified material in aqueous solution; the removal process followed the pseudo-second-order kinetic model more closely (Table S4). This is consistent with the results of Lyu et al., who reported that $\mathrm{Cr}(\mathrm{VI})$ removal with biochar-supported nanoscale iron sulfide composite fitted a pseudo-second-order kinetic model better, indicating that the rate-limiting step for $\mathrm{Cr}(\mathrm{VI})$ removal was chemisorption [5].

The $\mathrm{Cr}(\mathrm{VI})$ content in soil samples during aging, after $5 \%$ of the 0.5 or $1.0 \mathrm{CMC} @$ MMT-FeS, or $2.5 \mathrm{mmol} \mathrm{FeSO}_{4}$ were added to remediate the contaminated soil, is shown in Figure 3a: the immobilization of $\mathrm{Cr}(\mathrm{VI})$ in contaminated soil occurred mainly in the first 15 days, and the content of $\mathrm{Cr}(\mathrm{VI})$ in soil tended to stabilize after 15 days of remediation. The concentration of $\mathrm{Cr}(\mathrm{VI})$ in the soil showed a sharp decrease on the first day, and then a gradual decrease, becoming more stable. After aging for 30 days, the concentration of $\mathrm{Cr}(\mathrm{VI})$ in soil samples treated with $0.5 \mathrm{CMC} @ \mathrm{MMT}-\mathrm{FeS}$, 1.0 CMC@MMT-FeS, and $\mathrm{FeSO}_{4}$ decreased by 86, 90.7, and 76.3\%, respectively. Compared to the $\mathrm{FeSO}_{4}$ reagent, the composite containing the same molar content of $\mathrm{Fe}^{2+}$ immobilized $\mathrm{Cr}(\mathrm{VI})$ from the soil 9.6\% more efficiently. Comparing the FeS loading of the composite, 1.0 CMC@MMT-FeS immobilized $\mathrm{Cr}(\mathrm{VI})$ about $4.8 \%$ more efficiently than 0.5 CMC@MMT-FeS, when the proportion of composite added was $5 \%$.
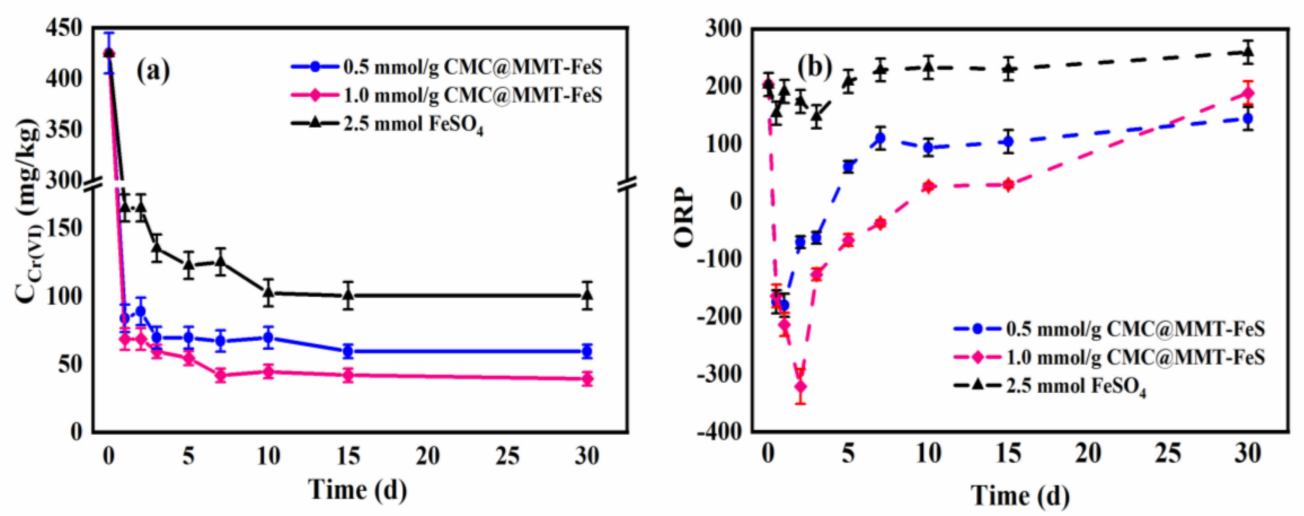

Figure 3. (a) The concentration of hexavalent chromium $(\mathrm{Cr}(\mathrm{VI}))$ and (b) the oxidation-reduction potential (ORP) of soil samples after amendments over 30 days (added composite-soil mass proportion: $5 \%$ ).

Figure $3 \mathrm{~b}$ shows the oxidation-reduction potential (ORP) of soil samples during the remediation process using the three treatments: after addition of $\mathrm{FeSO}_{4}$, the ORP of the soil environment decreased for the first three days, then gradually increased, reaching about $260 \mathrm{mV}$ after 30 days. After addition of 0.5 CMC@MMT-FeS, the soil ORP decreased to about $-180 \mathrm{mV}$ on the first day, and then increased gradually, reaching $60 \mathrm{mV}$ on the fifth day, and increasing to $144.5 \mathrm{mV}$ after $30 \mathrm{~d}$. After addition 
of 1.0 CMC@MMT-FeS, the soil ORP decreased to a minimum value of $-321 \mathrm{mV}$ after two days, and gradually increased to $26 \mathrm{mV}$ after 10 days, and to $188 \mathrm{mV}$ after 30 days. The ORP data reveal that the contaminated soil was oxidizable, and that the ORP of the soil went through two stages after the amendments: a sudden drop followed by a slow rise. Comparing the three remediation materials, the modified composite greatly reduced soil ORP and improved the redox capacity. Additionally, increases in FeS loading on the MMT surface improved the reduction ability of the composite.

The process of $\mathrm{Cr}(\mathrm{VI})$ reduction in the soil by the composites was similar to that of $\mathrm{Cr}(\mathrm{VI})$ alteration after reduction by nano-FeS particles, described by Li et al. [37], that is, decreasing sharply in $3 \mathrm{~d}$ and then reaching equilibrium slowly. The $\mathrm{Cr}(\mathrm{VI})$ immobilization efficiency of the composite was higher than that of $\mathrm{FeSO}_{4}$, and there are four potential explanations: (1) the $\mathrm{Fe}(\mathrm{II})$ in the loaded FeS was more stable and presented stronger reducibility; (2) in addition to Fe(II), the S(-II) in the modified composite might reduce the $\mathrm{Cr}(\mathrm{VI})$ in the soil under acidic conditions; (3) the surface properties of the MMT were improved after FeS loading; and (4) the adsorption of modified mineral materials contributed to $\mathrm{Cr}(\mathrm{VI})$ immobilization in soil.

\section{3. $\mathrm{Cr}(V I)$ Concentration in Soil Samples before and after Remediation}

Soil $\mathrm{Cr}(\mathrm{VI})$ before and after remediation with the 0.5 CMC@MMT-FeS and $\mathrm{FeSO}_{4}$ reagents was tested using TCLP, to study their effects on $\mathrm{Cr}(\mathrm{VI})$ immobilization. The TCLP leaching concentration of $\mathrm{Cr}(\mathrm{VI})$ in the untreated soil was $19.2 \mathrm{mg} / \mathrm{L}$ after 60 days (Figure $4 \mathrm{a}$ ). The addition of CMC@MMT-FeS at mass proportions of 1, 2, 3, 5, and $10 \%$ reduced the leaching concentration of $\mathrm{Cr}(\mathrm{VI})$ to $9.2,1.86,0.88$, 0.53 , and $0.12 \mathrm{mg} / \mathrm{L}$, respectively. This demonstrated that the composite reduced $\mathrm{Cr}(\mathrm{VI})$ in soil, and thus reduced the leachability and bioavailability of $\mathrm{Cr}(\mathrm{VI})$. After the addition of 2\% CMC@MMT-FeS, the $\mathrm{Cr}(\mathrm{VI})$ concentration in the TCLP extracts was substantially below the standard limit, and the remediated soil could be regarded as non-hazardous waste (China, GB 5085.3-2007) [65]. In contrast, $\mathrm{FeSO}_{4}$ reagent remediation (at $0.5,1.0,1.5,2.5$, and $5.0 \mathrm{mmol}$ ) reduced the leaching concentration of $\mathrm{Cr}(\mathrm{VI}) 13.28,10.41,6.93,1.17$, and $0.39 \mathrm{mg} / \mathrm{L}$, respectively. This suggests that CMC@MMT-FeS performed better than $\mathrm{FeSO}_{4}$ in immobilizing $\mathrm{Cr}(\mathrm{VI})$ under the same $\mathrm{Fe}(\mathrm{II})$ conditions. Adding composite at a composite-soil mass proportion of $2 \%$ (containing $1.0 \mathrm{mmol} \mathrm{Fe}(\mathrm{II})$ ) achieved the environmental protection standards for hazardous wastes, whereas $2.5 \mathrm{mmol} \mathrm{FeSO}_{4}$ reagent was needed to meet this standard. About twice as much $\mathrm{FeSO}_{4}$ reagent as composite was needed to achieve the same level of remediation.
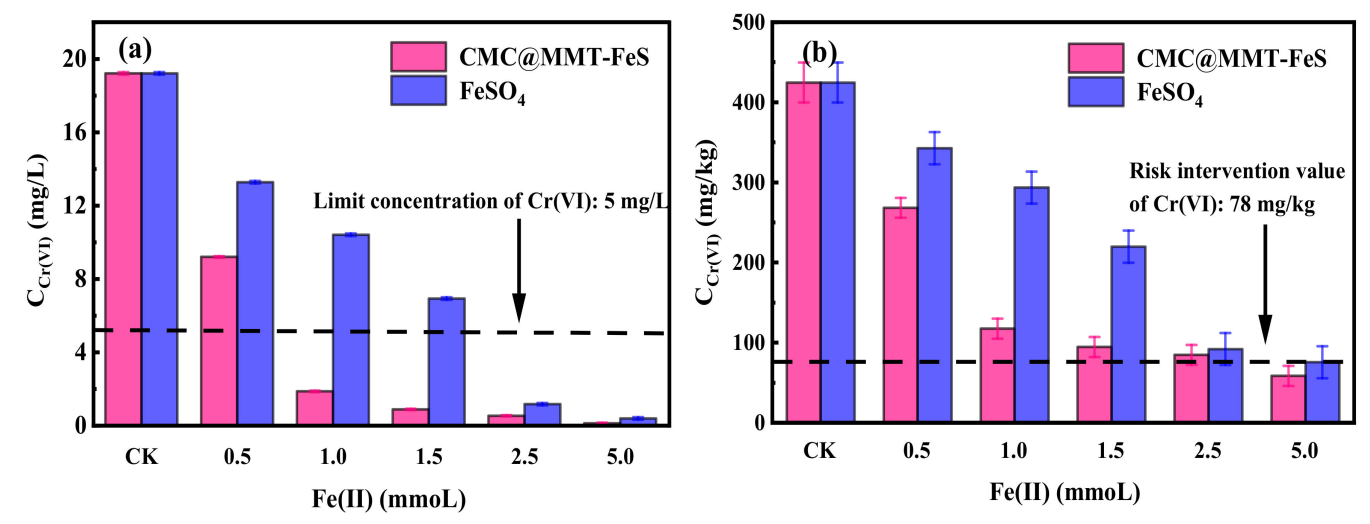

Figure 4. Concentration of $\mathrm{Cr}(\mathrm{VI})$ (a) in leaching by toxicity characteristic leaching procedure (TCLP) tests, and (b) in soil samples before and after soil remediation using 0.5 CMC@MMT-FeS (i.e., composite containing $\mathrm{FeS}$ at $0.5 \mathrm{mmol} / \mathrm{g}$ ) and the $\mathrm{FeSO}_{4}$ reagent. CK: control check.

Figure $4 \mathrm{~b}$ displays the $\mathrm{Cr}(\mathrm{VI})$ concentration in soil remediated by $0.5 \mathrm{CMC} @ \mathrm{MMT}-\mathrm{FeS}$ and $\mathrm{FeSO}_{4}$ reagents: the composite immobilized $\mathrm{Cr}(\mathrm{VI})$ more effectively than $\mathrm{FeSO}_{4}$ under the same amount of added Fe(II). In particular, at Fe(II) concentrations of about 1.0-1.5 mmol, the composite immobilized 
more than twice as much $\mathrm{Cr}(\mathrm{VI})$ than $\mathrm{FeSO}_{4}$ did. $\mathrm{The} \mathrm{Cr}(\mathrm{VI})$ concentration in soil amended by CMC@MMT-FeS and $\mathrm{FeSO}_{4}$ reagents (containing $5.0 \mathrm{mmol} \mathrm{Fe}(\mathrm{II})$ ) decreased from $424.6 \mathrm{mg} / \mathrm{kg}$ to 58.3 and $75.4 \mathrm{mg} / \mathrm{kg}$, respectively. This suggests that adding 0.5 CMC@MMT-FeS at a composite-soil mass proportion of $10 \%$ to the contaminated soil was able to meet the risk-intervention requirement value for second-class construction land (China, GB 36600-2018) [48]. Additionally, the total Cr concentration in the soil before and after remediation is presented in Figure S2, and the results indicated that the total $\mathrm{Cr}$ concentration in the soil decreased by $7.1-10.6 \%$ after the addition of composite materials at different proportions. In terms of leachability of $\mathrm{Cr}(\mathrm{VI})$ and the concentration of $\mathrm{Cr}(\mathrm{VI})$ and total $\mathrm{Cr}$ in soil, the novel CMC@MMT-FeS showed better performance in terms of immobilizing $\mathrm{Cr}(\mathrm{VI})$ in soil than $\mathrm{FeSO}_{4}$ reagents.

\subsection{BCR Tests of Soil Samples before and after Remediation}

The fractions of potential toxic metals in the soil influence their bioavailability and stability. The bioavailability of heavy metal fractions, ranked from highest to lowest, is as follows: acid-exchangeable (AE) fraction > reducible (RD) fraction $>$ oxidizable (OD) fraction $>$ residual (RS) fraction. The soil samples before and after the amendments were tested using the improved BCR procedure Figure 5: the abundances of the $\mathrm{Cr}$ fractions in the soil samples were ranked as follows: $\mathrm{AE}>\mathrm{RD}>\mathrm{OD}>\mathrm{RS}$. Figure 5 a shows the changes in the fractions of $\mathrm{Cr}$ in untreated and treated soils after the addition of 0.5 CMC@MMT-FeS at composite-soil mass proportions of 0, 1, 3, 5, and 10\%. The primary $\mathrm{Cr}$ fractions in the untreated soil were AE (44.7\%), RD (4.3\%), OD (28.1\%), and RS (22.9\%). As the proportion of composite added increased, the AE fraction decreased from 44.7 to 25.7, 8.2, 8.7, and 3.8\%, respectively, while the OD fraction increased from 28.1 to $48.3,53.5,54.1$, and $62.3 \%$, respectively. The addition of composite to the soil caused the RS fraction to increase by $5.2-9.1 \%$. With the increase in the dosage of $\mathrm{FeSO}_{4}(0.5,1.5,2.5$, or $5.0 \mathrm{mmol})$, the AE fraction decreased from 44.7 to $36.3,28.6,7.8$, and $4.1 \%$, respectively, while the OD fraction increased from 28.1 to $32.8,37.7,51.7$, and $53 \%$, respectively (Figure 5b). The RS fraction in the $\mathrm{FeSO}_{4}$-remediated soil samples increased by $3.2-14.5 \%$. No apparent changes in the RD fraction were detected in soil treated with composite or $\mathrm{FeSO}_{4}$ reagent. This suggests that the addition of composite caused the soil $\mathrm{Cr}$ fractions to change from $\mathrm{AE}$ to $\mathrm{OD}$ and RS, predominantly OD, accounting for the reduced leachability and enhanced stability of $\mathrm{Cr}(\mathrm{VI})$ in soil after treatment, thus reducing the toxicity of $\mathrm{Cr}(\mathrm{VI})$. According to the results of the present and previous studies, $\mathrm{Cr}_{2} \mathrm{O}_{3}, \mathrm{Cr}(\mathrm{OH})_{3}$, and $\mathrm{Cr}(\mathrm{III})-\mathrm{Fe}(\mathrm{III})$ oxides or hydroxides may have been formed during the remediation process [5,40]. Besides, the slight decrease in total $\mathrm{Cr}$ concentration in the remediated soil could be ascribed to the increase in the RS fraction of $\mathrm{Cr}$.
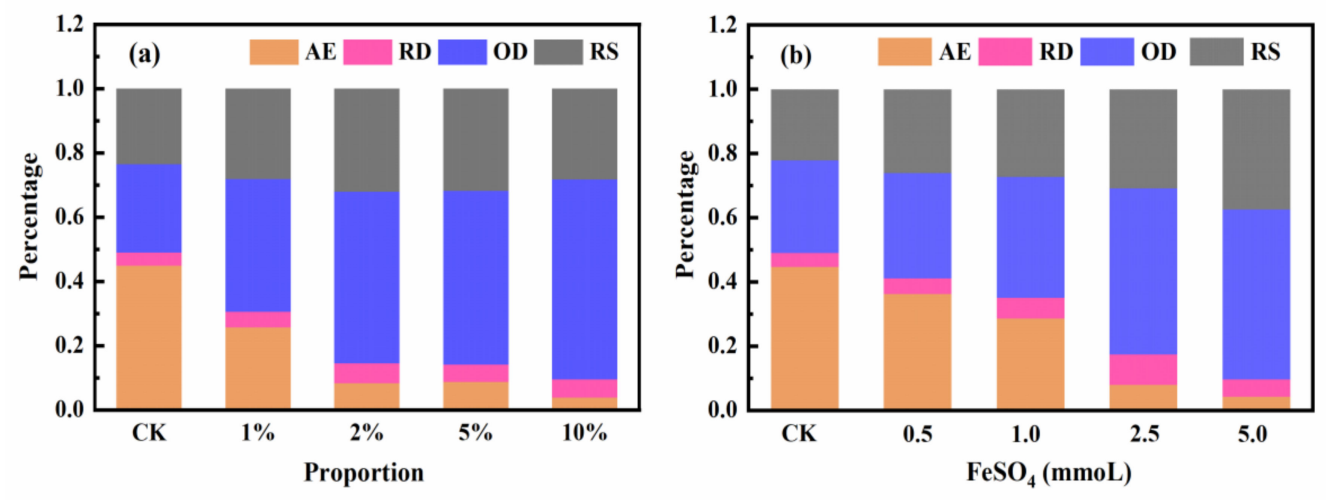

Figure 5. Proportion of $\mathrm{Cr}$ in each fraction of the soil samples before and after remediation with (a) 0.5 CMC@MMT-FeS; and (b) $\mathrm{FeSO}_{4}$ reagent. Fractions were measured using the modified BCR (European Community Bureau of Reference) method (AE, acid-exchangeable fraction; RD, reducible fraction; OD, oxidable fraction; RS, residual fraction). CK: control check. 


\subsection{The Mechanisms of Cr(VI) Immobilization by CMC@MMT-FeS}

The chemical composition of $\mathrm{Cr}, \mathrm{Fe}$, and $\mathrm{S}$ in the soil-sample surfaces, before and after $5 \%$ 0.5 CMC@MMT-FeS and $2.5 \mathrm{mmol} \mathrm{FeSO}_{4}$ reagent treatment, was detected using XPS; this was to investigate the mechanism of $\mathrm{Cr}(\mathrm{VI})$ immobilization in soils. Figure $6 \mathrm{a} 0$ shows the XPS spectra of $\mathrm{Cr} 2 \mathrm{p}$ on the soil surface, with three peaks in $\mathrm{Cr}(\mathrm{VI})$-contaminated soils, located at 577.7, 580.0, and 586.5 eV, corresponding to $\mathrm{Cr}_{2} \mathrm{O}_{3}, \mathrm{Cr}(\mathrm{OH})_{3}$, and $\mathrm{Cr}(\mathrm{VI})$, respectively $[37,66]$. The percentages of $\mathrm{Cr}(\mathrm{III})$ and $\mathrm{Cr}(\mathrm{VI})$ in the contaminated soil were about 44 and $56 \%$, respectively, of the chromium present. For the $\mathrm{FeSO}_{4}$-treated soil samples, as shown in Figure 6a1, the percentage of $\mathrm{Cr}(\mathrm{VI})$ on the soil surface decreased from 56 to $25.6 \%$, and that of $\mathrm{Cr}$ (III) increased from 44 to $74.5 \%$, of which $\mathrm{Cr}$ (III) in the $\mathrm{Cr}$ (III)-Fe(III) complex accounted for about 8.4\%. For 0.5 CMC@MMT-FeS-treated soil samples, the $\mathrm{Cr}(\mathrm{VI})$ peak in Figure $6 \mathrm{a} 2$ shifted slightly from 586.5 to $589.9 \mathrm{eV}$. Following 0.5 CMC@MMT-FeS treatment, the percentage of $\mathrm{Cr}(\mathrm{VI})$ decreased from 56 to $2.1 \%$, whereas that of $\mathrm{Cr}$ (III) increased from 44 to $98 \%$. Moreover, the $\mathrm{Cr}$ (III)-Fe(III) complex accounted for approximately $70 \%$ of the $\mathrm{Cr}$ present in the contaminated soil, indicating that the resulting $\mathrm{Cr}$ (III) combined with iron to form a stable iron-bound chromium compound in soils. These results demonstrate that $\mathrm{Cr}(\mathrm{VI})$ was converted to insoluble $\mathrm{Cr}$ (III) precipitate and was immobilized in soil after remediation [37]. Besides, the form of $\mathrm{Cr}$ in the composite-treated soil changed from acid-soluble fraction to iron-bound fraction after remediation.
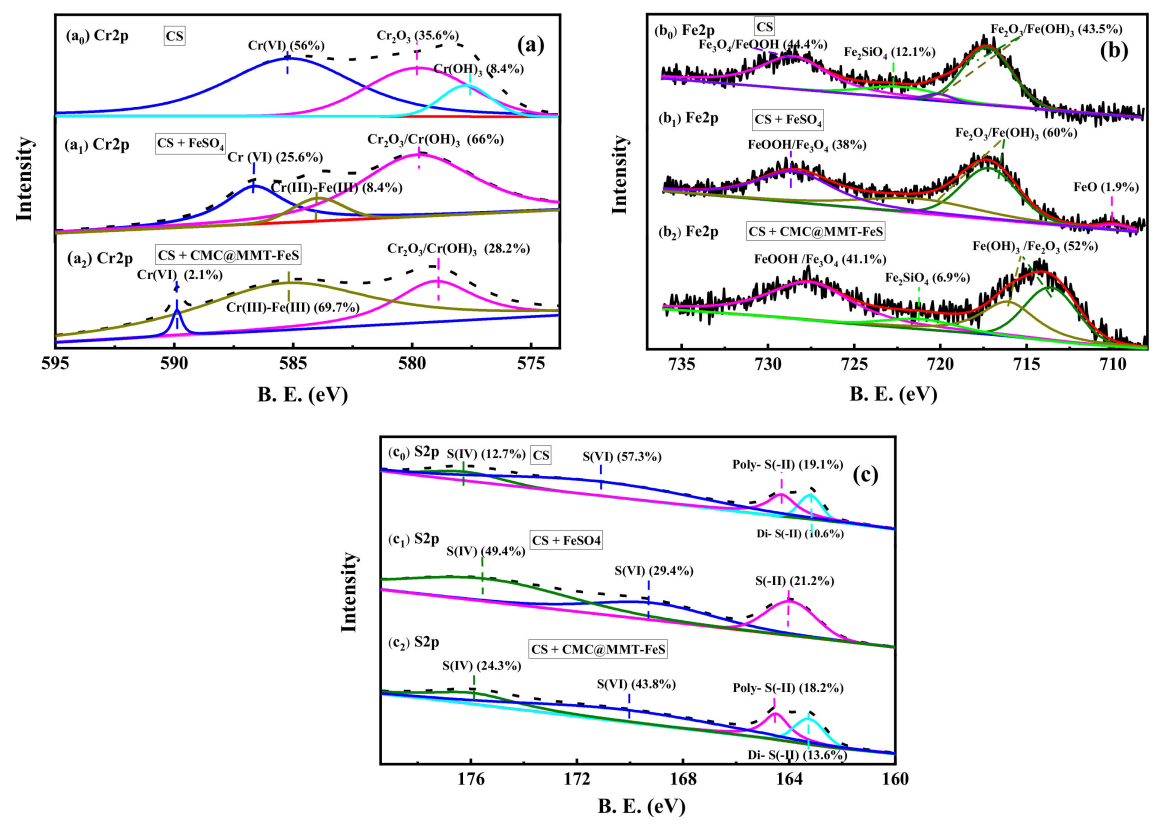

Figure 6. Chemical composition of (a) chromium (Cr), (b) iron (Fe), and (c) sulfur (S) in the surface of soil samples before and after treatment with 0.5 CMC@MMT-FeS and $\mathrm{FeSO}_{4}$ reagent.

Figure $6 b_{0}$ shows the Fe2p spectra from the untreated soil sample, with four peaks at 714.2, 717.6, 720.1, and $727.8 \mathrm{eV}$, corresponding to $\mathrm{Fe}_{2} \mathrm{O}_{3}, \mathrm{Fe}(\mathrm{OH})_{3}, \mathrm{Fe}_{2} \mathrm{SiO}_{4}$, and $\mathrm{Fe}_{3} \mathrm{O}_{4}$, respectively. For the $\mathrm{FeSO}_{4}$-treated soil samples (Figure $6 \mathrm{~b}_{1}$ ), the percentage of $\mathrm{Fe}_{2} \mathrm{O}_{3} / \mathrm{Fe}(\mathrm{OH})_{3}$ in the soil also increased, from 43.5 to $60 \%$ of the iron in the soil, after remediation. The peak of $\mathrm{Fe}(\mathrm{OH})_{3}$ shifted slightly, from 717.6 to $718.8 \mathrm{eV}$, and its percentage contribution to the iron in the soil increased from 2.6 to $23.8 \%$. For the 0.5 CMC@MMT-FeS-treated soil samples (Figure $6 b_{2}$ ), the $\mathrm{Fe}_{2} \mathrm{O}_{3} / \mathrm{Fe}(\mathrm{OH})_{3}$-binding energy shifted from 714.2 and 717.6, to 713.6 and $716.1 \mathrm{eV}$, and the peak of $\mathrm{Fe}_{2} \mathrm{SiO}_{4}$ shifted slightly from 720.1 to $721.1 \mathrm{eV}$. The iron elements in the FeS from the remediation materials were mainly converted $\mathrm{Fe}_{2} \mathrm{O}_{3} / \mathrm{Fe}(\mathrm{OH})_{3}$, which accounted for $52 \%$ of the iron in soil. These results show that the $\mathrm{Fe}(\mathrm{II})$ from the CMC@MMT-FeS was oxidized and formed Fe(III), which is likely to form a stable Fe(III)-Cr(III) complex in the soil during the $\mathrm{Cr}(\mathrm{VI})$ reduction process. 
Figure $6 \mathrm{c}$ shows the $\mathrm{S}$ on the soil-sample surfaces before and after treatment. The binding energy of S(VI) shifted slightly from 171.1 to $170 \mathrm{eV}$, and the percentage of S(VI) on the soil surface decreased from 57.3 to $43.8 \%$ of the $S$ in the soil, in the 0.5 CMC@MMT-FeS treatment. S(IV) binding energy shifted slightly from 176.2 to $175.9 \mathrm{eV}$, and the contribution of S(IV) increased from 12.7 to $24.3 \%$ of the $\mathrm{S}$ in the soil. The proportions of disulfide and polysulfide were essentially unchanged. This clarifies that the S(-II) component of the composite is oxidized to form the S(IV) compound when CMC@MMT-FeS is added to the soil.

According to the soil-sample physicochemical properties and XPS analysis, the following reactions account for the process of $\mathrm{Cr}(\mathrm{VI})$ removal and immobilization by modified materials [5]:

$$
\begin{gathered}
\mathrm{FeS}+\mathrm{H}_{2} \mathrm{O} \rightarrow \mathrm{Fe}^{2+}+\mathrm{HS}^{-}+\mathrm{OH}^{-} \\
3 \mathrm{Fe}^{2+}+\mathrm{HCrO}_{4}^{-}+\mathrm{H}^{+} \rightarrow 3 \mathrm{Fe}^{3+}+\mathrm{Cr}^{3+}+4 \mathrm{H}_{2} \mathrm{O} \\
\mathrm{HS}^{-}+2 \mathrm{HCrO}_{4}^{-}+7 \mathrm{H}^{+} \rightarrow \mathrm{SO}_{3}^{2-}+2 \mathrm{Cr}^{3+}+5 \mathrm{H}_{2} \mathrm{O} \\
\mathrm{Cr}^{3+}+3 \mathrm{OH}^{-} \rightarrow \mathrm{Cr}(\mathrm{OH})_{3} \\
x \mathrm{Cr}^{3+}+(1-\mathrm{x}) \mathrm{Fe}^{3+}+3 \mathrm{H}_{2} \mathrm{O} \rightarrow\left(\mathrm{Cr}_{\chi} \mathrm{Fe}_{1-\mathrm{X}}\right)(\mathrm{OH})_{3}+3 \mathrm{H}^{+}
\end{gathered}
$$

However, for the $\mathrm{FeSO}_{4}$ treatment, $\mathrm{Fe}(\mathrm{II})$ was the only electron donor in the remediated soil system, and thus $\mathrm{Cr}(\mathrm{VI})$ reduction was mainly achieved by two processes: Formulas (7) and (10).

\subsection{The Effect of Cr(VI) Remediation Evaluated Using the V. faba Micronucleus Method}

The micronucleus test is used to detect the number of micronuclei in $V$. faba root-tip meristem cells, which reflects the degree of damage to chromosomes in cells. The biotoxicity of $\mathrm{Cr}(\mathrm{VI})$ in the soil before and after 0.5 CMC@MMT-FeS remediation was determined using this method. The root inhibition rate (RIR) and PI were used to assess the effect of $\mathrm{Cr}(\mathrm{VI})$ remediation on $V$. faba (Table 1 ). In the CMC@MMT-FeS-remediation groups, the RIR decreased from 0.76 to 0.22 and the PI dropped from 0.68 to 0.20 with the increase in the composite-soil mass proportion from 1 to $10 \%$. This indicates that the biotoxicity for $V$. faba in the $\mathrm{Cr}(\mathrm{VI})$-contaminated soil was alleviated after composite remediation, which can also be seen from the elongation rate of $V$. faba root tips (Figure S3). The RIR and PI of the composite treatment groups were lower than those of the $\mathrm{FeSO}_{4}$ treatment groups, when $\mathrm{Fe}$ (II) was

\begin{tabular}{|c|c|c|c|}
\hline Treatment & $\mathrm{Cr}(\mathrm{VI})$ Concentration $(\mathrm{mg} / \mathrm{L})$ & RIR & PI \\
\hline CK & 0 & - & - \\
\hline CS & 40.75 & 0.79 & - \\
\hline $\begin{array}{c}\mathrm{CS}+1 \% 0.5 \\
\text { CMC@MMT-FeS }\end{array}$ & 21.21 & 0.76 & 0.68 \\
\hline $\begin{array}{c}\text { CS + } 5 \% 0.5 \\
\text { CMC@MMT-FeS }\end{array}$ & 1.61 & 0.24 & 0.31 \\
\hline $\begin{array}{c}\text { CS + 10\% } 0.5 \\
\text { CMC@MMT-FeS }\end{array}$ & 0.71 & 0.22 & 0.20 \\
\hline $\mathrm{CS}+0.5 \mathrm{mmol} \mathrm{FeSO}_{4}$ & 22.82 & 0.72 & 0.75 \\
\hline $\mathrm{CS}+2.5 \mathrm{mmol} \mathrm{FeSO}_{4}$ & 2.99 & 0.55 & 0.41 \\
\hline $\mathrm{CS}+5.0 \mathrm{mmol} \mathrm{FeSO}_{4}$ & 0.98 & 0.60 & 0.54 \\
\hline
\end{tabular}
added at 2.5 and $5.0 \mathrm{mmol}$. The results indicate that the toxicity of CMC@MMT-FeS on $V$. faba was less than that of $\mathrm{FeSO}_{4}$ at the same $\mathrm{Fe}(\mathrm{II})$ conditions, and this can be ascribed to the higher immobilization efficiency of the composite than $\mathrm{FeSO}_{4}$.

Table 1. Responses of Vicia faba to the soil Cr(VI) concentration before and after remediation.

RIR (root inhibition rate) $=1-\mathrm{L}_{\text {remediation }} / \mathrm{L}_{\mathrm{CK}} ; \mathrm{L}_{\text {remediation }}$ and $\mathrm{L}_{\mathrm{CK}}$ : mean root-tip length in the remediation and CK groups, respectively. PI (pollution index) $=\mathrm{MCN}_{\text {remediation }} / \mathrm{MCN}_{\mathrm{CK}} ; \mathrm{MCN}_{\text {remediation }}$ and $\mathrm{MCN}_{\mathrm{CK}}: V$. faba micronucleus rate in the remediation and CK groups, respectively. CK: Control check (background soil); CS: contaminated soil. Micronucleus rate $(\mathrm{MN})=\mathrm{N}_{\text {micronucleus }} / \mathrm{N}_{\text {dividing; }} ; \mathrm{N}_{\text {micronucleus }}$ and $\mathrm{N}_{\text {dividing: }}$ numbers of micronucleated cells and dividing cells, respectively. (-) No value. 


\subsection{The Effect of $\mathrm{Cr}(V I)$ Remediation Evaluated Using E. foetida}

Superoxide dismutase (SOD) is believed to be a biological indicator of the active oxidative-stress response mediated by pollutants. Peroxidase (POD) is used as one of the physiological indexes to assess the environmental biotoxicity of pollution. The activities of these enzymes (Table 2) reflected the degree to which E. foetida was subjected to contamination stress: the SOD activity levels of E. foetida on days 1 and 3 were higher than those of the control group, indicating that $\mathrm{Cr}(\mathrm{VI})$ causes the earthworms biological stress. On days 7 and 14 , all of the E. foetida individuals were dead in the highly contaminated soil (at the 1\% composite-soil mass proportion, and $0.5 \mathrm{mmol} \mathrm{FeSO}_{4}$ treatment), whereas they survived in the other treatments. This indicates that the toxic stress caused by $\mathrm{Cr}(\mathrm{VI})$ on E. foetida was alleviated when enough of the composite was added. For treatment groups with different amount of composite, the comparison of SOD activity levels in 5 and $10 \%$ groups and 1 and $2 \%$ groups was not obvious. The E. foetida SOD activity level was higher at the $5 \%$ than at the $10 \%$ composite-soil mass proportion. This shows that the toxic stress experienced by E. foetida was not greatly reduced with the decrease of the $\mathrm{Cr}(\mathrm{VI})$ concentration in composite treated-soils. The E. foetida POD activity levels increased in the first three days, which indicates that the stress on E. foetida caused by $\mathrm{Cr}(\mathrm{VI})$ was enhanced by the addition of the composite. From 3 to 14 days, the POD values decreased, demonstrating that the stress on E. foetida was reduced. POD activity was higher at the $1 \%$ composite-soil mass proportion than for the other treatments (from days 1-3), mainly because the $\mathrm{Cr}(\mathrm{VI})$ concentration was higher in the soil; at 14 days, all of the E. foetida in the $1 \%$ composite-soil mass proportion treatment were dead. However, the POD activity level did not change distinctly with the amount of composite added. In summary, E. foetida experienced less toxic stress from the $\mathrm{Cr}(\mathrm{VI})$ contaminated soil after 5 or $10 \%$ added composite treatment.

Table 2. Enzyme activity of Eisenia foetida in soil samples on different days.

\begin{tabular}{|c|c|c|c|c|c|c|c|c|}
\hline \multirow{2}{*}{ Treatment } & \multicolumn{4}{|c|}{ SOD Values (U/mg Protein) } & \multicolumn{4}{|c|}{ POD Values (U/mg Protein) } \\
\hline & $1 \mathrm{~d}$ & $3 \mathrm{~d}$ & $7 \mathrm{~d}$ & $14 \mathrm{~d}$ & $1 \mathrm{~d}$ & $3 \mathrm{~d}$ & $7 \mathrm{~d}$ & $14 \mathrm{~d}$ \\
\hline CK & 1.93 & 4.89 & 8.91 & 9.40 & 6.81 & 9.40 & 8.03 & 7.08 \\
\hline $\begin{array}{c}\text { CS + 1\% } 0.5 \\
\text { CMC@MMT-FeS }\end{array}$ & 6.86 & 7.28 & 3.83 & * & 7.75 & 10.82 & 8.19 & * \\
\hline $\begin{array}{c}\mathrm{CS}+5 \% 0.5 \\
\text { CMC@MMT-FeS }\end{array}$ & 11.67 & 13.27 & 8.32 & 5.9 & 6.16 & 8.24 & 8.23 & 7.02 \\
\hline $\begin{array}{c}\text { CS + 10\% } 0.5 \\
\text { CMC@MMT-FeS }\end{array}$ & 9.82 & 12.42 & 7.45 & 3.65 & 6.04 & 8.46 & 8.11 & 7.04 \\
\hline $\mathrm{CS}+0.5 \mathrm{mmol} \mathrm{FeSO}_{4}$ & 5.90 & 8.28 & * & * & 8.04 & 9.75 & * & * \\
\hline $\mathrm{CS}+2.5 \mathrm{mmol} \mathrm{FeSO}_{4}$ & 8.96 & 7.96 & 7.6 & 6.30 & 6.37 & 9.24 & 8.11 & 7.15 \\
\hline $\mathrm{CS}+5.0 \mathrm{mmol} \mathrm{FeSO}_{4}$ & 6.61 & 9.82 & 11.73 & 11.03 & 6.48 & 9.16 & 8.16 & 7.25 \\
\hline
\end{tabular}

\section{Conclusions}

The study describes the efficacy of a novel CMC@MMT-FeS composite, which was prepared to remediate $\mathrm{Cr}$ (VI)-contaminated soils. The $\mathrm{Cr}(\mathrm{VI})$-removal capacity of CMC@MMT-FeS was enhanced by increasing the FeS-particle loading. The immobilization of $\mathrm{Cr}(\mathrm{VI})$ in contaminated soil occurred mainly in the first 15 days (a sharp decrease on the first day, followed by a gradual decrease); the content of $\mathrm{Cr}(\mathrm{VI})$ in soil tended to stabilize after 15 days. CMC@MMT-FeS performed better than the $\mathrm{FeSO}_{4}$ reagent when the same amount of $\mathrm{Fe}(\mathrm{II})$ was added to soil samples. The soil $\mathrm{Cr}(\mathrm{VI})$ concentration decreased by 86.3\% after 30 days when 0.5 CMC@MMT-FeS was added to the contaminated soil at a composite-soil mass proportion of $10 \%$ : we suggest that this dose could meet the risk-intervention requirement value for second-class construction land. Further, the soil $\mathrm{Cr}$ fractions changed from AE to mainly OD and RS after composite remediation, but predominantly to OD. The Fe(III)-Cr(III) complex was the primary product of the remediation process by CMC@MMT-FeS. Biotoxicity, assessed using V. faba and E. foetida, 
was greatly reduced by remediation. These findings demonstrate that CMC@MMT-FeS is a promising material for remediating $\mathrm{Cr}(\mathrm{VI})$-contaminated soils.

Supplementary Materials: The following are available online at http://www.mdpi.com/1660-4601/17/17/6087/s1, Section 1: Pretreatment of montmorillonite (MMT). Section 2: Modified European Community Bureau of Reference (BCR) sequential extraction tests. Section 3: Pretreatment of Vicia faba seedlings for root micronucleus tests. Section 4: Preparation of the soil extract for the Vicia faba micronucleus test. Section 5: Removal of Cr(VI) by CMC@MMT-FeS in aqueous solution. Table S1: Physical and chemical properties of the contaminated soil samples. Table S2: Solutions used in the modified European Community Bureau of Reference (BCR) method. Table S3: Concentration of $\mathrm{Cr}(\mathrm{VI})$ in soil samples for the Eisenia foetida experiments. Table S4: Fitting parameters of the kinetic model of $\mathrm{Cr}(\mathrm{VI})$ removal in aqueous solution. Figure S1: Effect of FeS loading on $\mathrm{Cr}(\mathrm{VI}) \mathrm{removal}$ efficiency in aqueous solution. Figure S2: Total $\mathrm{Cr}$ in the contaminated soil before and after remediation. Figure S3: Elongation rate of Vicia faba root tips in different treatment groups.

Author Contributions: Conceptualization D.Z. (Dexun Zou) Data curation X.L., L.W. Formal analysis X.H. Project administration Y.M., D.Z.(Dexun Zou). Resources Y.M. Supervision C.L., Y.M. Visualization Z.L. Writing一original draft D.Z. (Dading Zhang), Y.X. Writing-review \& editing D.Z. (Dading Zhang), Y.X., Y.M., D.Z. (Dexun Zou). All authors have read and agreed to the published version of the manuscript.

Funding: This study was financially supported by the National Key Research and Development Program of China [grant number 2018YFC1800800], the Yue Qi Young Scholar Project, China University of Mining \& Technology, Beijing [grant number 2019QN09], and the Fundamental Research Funds for the Central Universities [grant number 2020SKHH01].

Conflicts of Interest: The authors declare no conflict of interest.

\section{References}

1. Paul, D. Research on heavy metal pollution of river Ganga: A review. Ann. Agrar. Sci. 2017, 15, $278-286$. [CrossRef]

2. Qing, X.; Yutong, Z.; Shenggao, L. Assessment of heavy metal pollution and human health risk in urban soils of steel industrial city (Anshan), Liaoning, Northeast China. Ecotoxicol. Environ. Saf. 2015, 120, 377-385. [CrossRef] [PubMed]

3. Yang, Q.; Li, Z.; Lu, X.; Duan, Q.; Huang, L.; Bi, J. A review of soil heavy metal pollution from industrial and agricultural regions in China: Pollution and risk assessment. Sci. Total. Environ. 2018, 642, 690-700. [CrossRef] [PubMed]

4. Fontaine, M.; Clement, Y.; Blanc, N.; Demesmay, C. Hexavalent chromium release from leather over time natural ageing vs accelerated ageing according to a multivariate approach. J. Hazard. Mater. 2019, 368, 811-818. [CrossRef] [PubMed]

5. Lyu, H.; Tang, J.; Huang, Y.; Gai, L.; Zeng, E.Y.; Liber, K.; Gong, Y. Removal of hexavalent chromium from aqueous solutions by a novel biochar supported nanoscale iron sulfide composite. Chem. Eng. J. 2017, 322, 516-524. [CrossRef]

6. Choppala, G.; Kunhikrishnan, A.; Seshadri, B.; Park, J.H.; Bush, R.; Bolan, N. Comparative sorption of chromium species as influenced by $\mathrm{pH}$, surface charge and organic matter content in contaminated soils. J. Geochem. Explor. 2018, 184, 255-260. [CrossRef]

7. Lukina, A.; Boutin, C.; Rowland, O.; Carpenter, D. Evaluating trivalent chromium toxicity on wild terrestrial and wetland plants. Chemosphere 2016, 162, 355-364. [CrossRef]

8. Samani, M.R.; Ebrahimbabaie, P.; Molamahmood, H.V. Hexavalent chromium removal by using synthesis of polyaniline and polyvinyl alcohol. Water Sci. Technol. 2016, 74, 2305-2313. [CrossRef]

9. Adam, M.R.; Salleh, N.M.; Jaafar, J.; Matsuura, T.; Ali, M.H.; Jaafar, J.; Ismail, A.F.; Rahman, M.A.; Jaafar, J. The adsorptive removal of chromium (VI) in aqueous solution by novel natural zeolite based hollow fibre ceramic membrane. J. Environ. Manag. 2018, 224, 252-262. [CrossRef]

10. Sun, H.; Brocato, J.; Costa, M. Oral chromium exposure and toxicity. Curr. Environ. Heal. Rep. 2015, 2, $295-303$. [CrossRef]

11. Wise, J.T.F.; Wang, L.; Zhang, Z.; Shi, X. The 9th conference on metal toxicity and carcinogenesis: The conference overview. Toxicol. Appl. Pharmacol. 2017, 331, 1-5. [CrossRef]

12. Dhal, B.; Thatoi, H.; Das, N.; Pandey, B.D. Chemical and microbial remediation of hexavalent chromium from contaminated soil and mining/metallurgical solid waste: A review. J. Hazard. Mater. 2013, 272-291. [CrossRef] [PubMed] 
13. Meng, Y.; Zhao, Z.; Burgos, W.D.; Li, Y.; Zhang, B.; Wang, Y.; Liu, W.; Sun, L.; Lin, L.; Luan, F. Iron(III) minerals and anthraquinone-2,6-disulfonate (AQDS) synergistically enhance bioreduction of hexavalent chromium by Shewanella oneidensis MR-1. Sci. Total. Environ. 2018, 591-598. [CrossRef]

14. Apte, A.D.; Verma, S.; Tare, V.; Bose, P. Oxidation of $\mathrm{Cr}(\mathrm{III})$ in tannery sludge to $\mathrm{Cr}(\mathrm{VI})$ : Field observations and theoretical assessment. J. Hazard. Mater. 2005, 121, 215-222. [CrossRef] [PubMed]

15. Di Palma, L.; Gueye, M.; Petrucci, E. Hexavalent chromium reduction in contaminated soil: A comparison between ferrous sulphate and nanoscale zero-valent iron. J. Hazard. Mater. 2015, 281, 70-76. [CrossRef]

16. Zhang, S.; Lyu, H.; Tang, J.; Song, B.; Zhen, M.; Liu, X. A novel biochar supported CMC stabilized nano zero-valent iron composite for hexavalent chromium removal from water. Chemosphere 2019, 217, 686-694. [CrossRef]

17. Zhao, L.; Ding, Z.; Sima, J.; Xu, X.; Cao, X. Development of phosphate rock integrated with iron amendment for simultaneous immobilization of $\mathrm{Zn}$ and $\mathrm{Cr}(\mathrm{VI})$ in an electroplating contaminated soil. Chemosphere 2017, 182, 15-21. [CrossRef] [PubMed]

18. Chen, J.; Wang, Y.; Zhou, S.; Lei, X. Reduction/immobilization processes of hexavalent chromium using metakaolin-based geopolymer. J. Environ. Chem. Eng. 2017, 5, 373-380. [CrossRef]

19. Mamais, D.; Noutsopoulos, C.; Kavallari, I.; Nyktari, E.; Kaldis, A.; Panousi, E.; Nikitopoulos, G.; Antoniou, K.; Nasioka, M. Biological groundwater treatment for chromium removal at low hexavalent chromium concentrations. Chemosphere 2016, 152, 238-244. [CrossRef]

20. Nikolić, V.; Komljenovic, M.; Džunuzović, N.; Ivanović, T.; Miladinović, Z. Immobilization of hexavalent chromium by fly ash-based geopolymers. Compos. Part B Eng. 2017, 112, 213-223. [CrossRef]

21. Hawley, E.L.; Deeb, R.A.; Kavanaugh, M.C.; Jacobs, J.A. Treatment technologies for chromium(VI). In Chromium(VI) Handbook; Jacques, G., Jamea, A.J., Cynthia, P.A., Eds.; CRC Press: Boca Raton, FL, USA, 2005; p. 284.

22. Athanasekou, C.; Romanos, G.; Papageorgiou, S.; Manolis, G.; Katsaros, F.K.; Falaras, P. Photocatalytic degradation of hexavalent chromium emerging contaminant via advanced titanium dioxide nanostructures. Chem. Eng. J. 2017, 318, 171-180. [CrossRef]

23. Kang, S.; Wang, G.; Zhao, H.; Cai, W. Highly efficient removal of hexavalent chromium in aqueous solutionsviachemical reduction of plate-like micro/nanostructured zero valent iron. RSC Adv. 2017, 7, 55905-55911. [CrossRef]

24. Petala, E.; Baikousi, M.; Vasilopoulos, K.C.; Karakassides, M.A.; Zoppellaro, G.; Filip, J.; Tucekc, J.; Pechoušek, J.; Zbořil, R. Synthesis, physical properties and application of the zero-valent iron/titanium dioxide heterocomposite having high activity for the sustainable photocatalytic removal of hexavalent chromium in water. Phys. Chem. Chem. Phys. 2016, 18, 10637-10646. [CrossRef] [PubMed]

25. Bishop, M.E.; Glasser, P.; Dong, H.; Arey, B.W.; Kovarik, L. Reduction and immobilization of hexavalent chromium by microbially reduced Fe-bearing clay minerals. Geochim. Cosmochim. Acta 2014, 133, 186-203. [CrossRef]

26. Liu, Y.; Mou, H.; Chen, L.; Mirza, Z.A.; Liu, L. Cr(VI)-contaminated groundwater remediation with simulated permeable reactive barrier (PRB) filled with natural pyrite as reactive material: Environmental factors and effectiveness. J. Hazard. Mater. 2015, 298, 83-90. [CrossRef]

27. Mullet, M.; Boursiquot, S.; Ehrhardt, J.-J. Removal of hexavalent chromium from solutions by mackinawite, tetragonal FeS. Colloids Surfaces A Physicochem. Eng. Asp. 2004, 244, 77-85. [CrossRef]

28. Parthasarathy, G.; Choudary, B.M.; Sreedhar, B.; Kunwar, A.C. Environmental mineralogy: Spectroscopic studies on ferrous saponite and the reduction of hexavalent chromium. Nat. Hazards 2006, 40, 647-655. [CrossRef]

29. Kwak, S.; Yoo, J.-C.; Moon, D.H.; Baek, K. Role of clay minerals on reduction of Cr(VI). Geoderma 2018, 312, 1-5. [CrossRef]

30. Zhang, T.T.; Xue, Q.; Li, J.-S.; Wei, M.-L.; Wang, P.; Liu, L.; Wan, Y. Effect of ferrous sulfate dosage and soil particle size on leachability and species distribution of chromium in hexavalent chromium-contaminated soil stabilized by ferrous sulfate. Environ. Prog. Sustain. Energy 2018, 38, 500-507. [CrossRef]

31. Dong, H.; Deng, J.; Xie, Y.; Zhang, C.; Jiang, Z.; Cheng, Y.; Hou, K.; Zeng, G. Stabilization of nanoscale zero-valent iron (nZVI) with modified biochar for $\mathrm{Cr}(\mathrm{VI})$ removal from aqueous solution. J. Hazard. Mater. 2017, 332, 79-86. [CrossRef] 
32. Qian, L.; Zhang, W.; Yan, J.; Han, L.; Chen, Y.; Ouyang, D.; Chen, M. Nanoscale zero-valent iron supported by biochars produced at different temperatures: Synthesis mechanism and effect on $\mathrm{Cr}(\mathrm{VI})$ removal. Environ. Pollut. 2017, 223, 153-160. [CrossRef] [PubMed]

33. Xu, C.; Yang, W.; Liu, W.; Sun, H.; Jiao, C.; Lin, A. Performance and mechanism of Cr(VI) removal by zero-valent iron loaded onto expanded graphite. J. Environ. Sci. 2018, 67, 14-22. [CrossRef]

34. Zhou, L.; Li, R.; Zhang, G.; Wang, N.; Cai, D.; Wu, Z. Zero-valent iron nanoparticles supported by functionalized waste rock wool for efficient removal of hexavalent chromium. Chem. Eng. J. 2018, 339, 85-96. [CrossRef]

35. Rivero-Huguet, M.; Marshall, W.D. Reduction of hexavalent chromium mediated by micro-And nano-sized mixed metallic particles. J. Hazard. Mater. 2009, 169, 1081-1087. [CrossRef] [PubMed]

36. Han, D.S.; Orillano, M.; Khodary, A.; Duan, Y.; Batchelor, B.; Abdel-Wahab, A. Reactive iron sulfide (FeS)-supported ultrafiltration for removal of mercury ( $\mathrm{Hg}(\mathrm{II}))$ from water. Water Res. 2014, 53, 310-321. [CrossRef]

37. Lyu, H.; Zhao, H.; Tang, J.; Gong, Y.; Huang, Y.; Wu, Q.; Gao, B. Immobilization of hexavalent chromium in contaminated soils using biochar supported nanoscale iron sulfide composite. Chemosphere 2018, 194, 360-369. [CrossRef]

38. Zhang, H.; Peng, L.; Chen, A.; Shang, C.; Lei, M.; He, K.; Luo, S.; Shao, J.; Zeng, Q. Chitosan-stabilized FeS magnetic composites for chromium removal: Characterization, performance, mechanism, and stability. Carbohydr. Polym. 2019, 214, 276-285. [CrossRef]

39. Liu, Y.; Xiao, W.; Wang, J.; Mirza, Z.A.; Wang, T. Optimized synthesis of fes nanoparticles with a high Cr(VI) removal capability. J. Nanomater. 2016, 2016, 1-9. [CrossRef]

40. Li, Y.; Wang, W.; Zhou, L.; Liu, Y.; Mirza, Z.A.; Lin, X. Remediation of hexavalent chromium spiked soil by using synthesized iron sulfide particles. Chemosphere 2017, 169, 131-138. [CrossRef]

41. Yang, H.; Hong, M.; Chen, S. Removal of $\mathrm{Cr}(\mathrm{VI})$ with nano-FeS and CMC-FeS and transport properties in porous media. Environ. Technol. 2019, 1-11. [CrossRef]

42. He, F.; Zhao, D. Manipulating the size and dispersibility of zerovalent iron nanoparticles by use of carboxymethyl cellulose stabilizers. Environ. Sci. Technol. 2007, 41, 6216-6221. [CrossRef] [PubMed]

43. Ren, H.; Gao, Z.; Wu, D.; Jiang, J.; Sun, Y.; Luo, C. Efficient Pb(II) removal using sodium alginate-carboxymethyl cellulose gel beads: Preparation, characterization, and adsorption mechanism. Carbohydr. Polym. 2016, 137, 402-409. [CrossRef] [PubMed]

44. Wang, Y.; Fang, Z.; Liang, B.; Tsang, E.P. Remediation of hexavalent chromium contaminated soil by stabilized nanoscale zero-valent iron prepared from steel pickling waste liquor. Chem. Eng. J. 2014, 247, 283-290. [CrossRef]

45. Bermúdez, Y.H.; Truffault, L.; Pulcinelli, S.; Santilli, C.V. Sodium montmorillonite/ureasil-poly(oxyethylene) nanocomposite as potential adsorbent of cationic dye. Appl. Clay Sci. 2018, 152, 158-165. [CrossRef]

46. Zeynizadeh, B.; Rahmani, S.; Tizhoush, H. The immobilized Cu nanoparticles on magnetic montmorillonite (MMT@Fe3O4@Cu): As an efficient and reusable nanocatalyst for reduction and reductive-acetylation of nitroarenes with NaBH4. Polyhedron 2019, 175, 114201. [CrossRef]

47. Volzone, C. Retention of pollutant gases: Comparison between clay minerals and their modified products. Appl. Clay Sci. 2007, 36, 191-196. [CrossRef]

48. Ministry of Ecology and Environment of the People's Republic of China. Soil Environmental Quality-Risk Control Standard for Soil Contamination of Development Land; Ministry of Ecology and Environment of the People's Republic of China: Beijing, China, 2018.

49. Ministry of Environmental Protection of the People's Republic of China. Solid Waste. Extraction Procedure for Leaching Toxicity. Acetic Acid Buffer Solution Method; Ministry of Ecology and Environment of the People's Republic of China: Beijing, China, 2007.

50. Ure, A.; Quevauviller, P.H.; Muntau, H.; Griepink, B. 1992. EUR Report EN 14472; European Commission: Brussels, Belgium, 1992.

51. Rauret, G.; López-Sánchez, J.F.; Sahuquillo, A.; Rubio, R.; Davidson, C.M.; Ure, A.; Quevauviller, P. Improvement of the BCR three step sequential extraction procedure prior to the certification of new sediment and soil reference materials. J. Environ. Monit. 1999, 1, 57-61. [CrossRef] 
52. Khadra, A.; Pinelli, E.; Ezzariai, A.; Mohamed, O.; Merlina, G.; Lyamlouli, K.; Kouisni, L.; Hafidi, M. Assessment of the genotoxicity of antibiotics and chromium in primary sludge and compost using Vicia faba micronucleus test. Ecotoxicol. Environ. Saf. 2019, 185, 109693. [CrossRef]

53. Tang, R.; Ding, C.; Ma, Y.; Wang, J.-S.; Zhang, T.; Wang, X. Metabolic responses of eisenia fetida to individual $\mathrm{Pb}$ and Cd contamination in two types of soils. Sci. Rep. 2017, 7, 13110. [CrossRef]

54. Kanaya, N.; Gill, B.; Grover, I.; Murin, A.; Osiecka, R.; Sandhu, S.; Andersson, H. Vicia faba chromosomal aberration assay. Mutat. Res. Mol. Mech. Mutagen. 1994, 310, 231-247. [CrossRef]

55. Wang, H. Clastogenicity of chromium contaminated soil samples evaluated by Vicia root-micronucleus assay. Mutat. Res. Mol. Mech. Mutagen. 1999, 426, 147-149. [CrossRef]

56. Hu, Y.; Zhang, S.-H.; Zuo, Y.-T.; Liu, N.; Tan, L.; Han, X.; Lu, W.-Q.; Liu, A.-L. Detection of genotoxic effects of drinking water disinfection by-products using Vicia faba bioassay. Environ. Sci. Pollut. Res. 2016, 24, 1509-1517. [CrossRef] [PubMed]

57. Sivakumar, S.; Subbhuraam, C. Toxicity of chromium(III) and chromium(VI) to the earthworm Eisenia fetida. Ecotoxicol. Environ. Saf. 2005, 62, 93-98. [CrossRef] [PubMed]

58. Ministry of Environmental Protection of the People's Republic of China. Solid Waste. Determination of Hexavalent Chromium. Alkaline Digestion/Flame Atomic Absorption Spectrophotometric; Ministry of Ecology and Environment of the People's Republic of China: Beijing, China, 2014.

59. Ministry of Environmental Protection of the People's Republic of China. Water Quality. Determination of Chromium(VI). 1,5 Diphenylcarbohydrazide Spectrophotometric Method; Ministry of Ecology and Environment of the People's Republic of China: Beijing, China, 1987.

60. Li, Y.; Yin, J.; Chu, C.; Sui, N.; Shi, S.; Wei, J.; Di, F.; Guo, J.; Wang, C.; Xu, W.; et al. Earth-abundant Fe1-xS@S-doped graphene oxide nano-micro composites as high-performance cathode catalysts for green solar energy utilization: fast interfacial electron exchange. RSC Adv. 2018, 8, 4340-4347. [CrossRef]

61. Shi, M.; Wu, T.; Song, X.; Liu, J.; Zhao, L.; Zhang, P.; Gao, L. Active Fe 2 O 3 nanoparticles encapsulated in porous g-C $3 \mathrm{~N}$ 4/graphene sandwich-type nanosheets as a superior anode for high-performance lithium-ion batteries. J. Mater. Chem. A 2016, 4, 10666-10672. [CrossRef]

62. Ji, X.; Li, B.; Yuan, B.; Guo, M. Preparation and characterizations of a chitosan-based medium-density fiberboard adhesive with high bonding strength and water resistance. Carbohydr. Polym. 2017, 176, 273-280. [CrossRef]

63. Talari, A.C.S.; Martinez, M.A.G.; Movasaghi, Z.; Rehman, S.; Rehman, I.U. Advances in Fourier transform infrared (FTIR) spectroscopy of biological tissues. Appl. Spectrosc. Rev. 2016, 52, 1-51. [CrossRef]

64. Auta, M.; Hameed, B. Adsorption of carbon dioxide by diethanolamine activated alumina beads in a fixed bed. Chem. Eng. J. 2014, 253, 350-355. [CrossRef]

65. Ministry of Environmental Protection of the People's Republic of China. Identification Standards for Hazardous Waste_Identification for Extraction Toxicity; Ministry of Ecology and Environment of the People's Republic of China: Beijing, China, 2007.

66. Biesinger, M.C.; Payne, B.P.; Grosvenor, A.; Lau, L.W.; Gerson, A.R.; Smart, R.S. Resolving surface chemical states in XPS analysis of first row transition metals, oxides and hydroxides: $\mathrm{Cr}, \mathrm{Mn}, \mathrm{Fe}$, Co and $\mathrm{Ni}$. Appl. Surf. Sci. 2011, 257, 2717-2730. [CrossRef]

(C) 2020 by the authors. Licensee MDPI, Basel, Switzerland. This article is an open access article distributed under the terms and conditions of the Creative Commons Attribution (CC BY) license (http://creativecommons.org/licenses/by/4.0/). 